\title{
VALOKUVA JA ME
}

Janne Seppänen: Levoton valokuva. Tampere: Vastapaino 2014.

"Sinä painat nappia, me teemme loput" oli iskulause, jolla Kodak mainosti uutta nro 1 laatikkokameraansa 125 vuotta sitten. Sittemmin sekä "me" että "loput" ovat muuttuneet radikaalisti vaikka nappia painavan sormen tasolla asiat ovatkin lähestulkoon ennallaan. Nappi ei vain laukaise mekanismia kamerassa vaan merkkaa samalla kuvanottotapahtuman osaksi verkottuneiden kameroiden ja erilaisten kuvanjakoalustojen globaalia viitekehikkoa. Valokuvien kehittämisen ympärille rakentunut teollisuus on kuihtunut ja korvautunut erilaisilla informaationhallintajärjestelmillä, joista vain pieni osa palvelee valokuvien tulostamista paperille. Yhä useammat kuvat päätyvät albumien sijaan pilvipalvelimille ja sosiaaliseen mediaan. Valokuvauksen materiaaliset reunaehdot ovat muuttuneet digitalisoitumisen myötä kauaskantoisella tavalla. Janne Seppäsen Levoton valokurva hahmottelee tähän murrokseen liittyviä kysymyksiä valokuvan materiaalisen ytimen näkökulmasta.

Valokuvaus on kaikkea muuta kuin kuollut. Nykytilannetta voi verrata valokuvauksen keksimistä seuranneisiin nopean monipuolistumisen ja rikkaan kuvakulttuurin vuosikymmeniin 1800-luvun puolivälissä. Kun François Arago esitteli Louis Daguerren ja Nicéphore Niépcen kehittelemän valokuvausmenetelmän Ranskan tiedeakatemialle vuonna 1839, hän hahmotteli sille laajan kirjon mahdollisia sovellutusalueita tähtitieteestä maalaustaiteeseen. Nykyään laskennallinen valokuvaus avaa ennennäkemättömiä mahdollisuuksia valon kuvautumisen säännönmukaisuuksien hallinnalle ja erittelylle avaruusluotainkuvista kasvontunnistukseen.
Valokuvia otetaan päivittäin enemmän kuin koskaan ennen, mutta valokuvien elinkaareen kohdistuvat odotukset ovat muuttuneet. Menneen hetken ikuistamisen sijaan valokuvauksen valtavirran keskiössä on ohikiitävän nykyhetken jakaminen. Tilastot puhuvat puolestaan: lyhytkestoisten valokuvien jakamiseen erikoistuneella Snapchat-palvelulla oli vuonna 2013 yli 26 miljoonaa kuukausittaista käyttäjää yksinomaan Yhdysvalloissa. Samalla kun valokuva yhä useammin on tallenteen sijaan läsnäolon signaali, niin maailman visuaalinen kolonialisointi on edennyt siihen pisteeseen, että oma naama alkaa olla yleisin kuvauskohde.

Vuonna 2001 Janne Seppänen antoi väitöskirjalleen otsikon "Valokuvaa ei ole". Tuolloin valokuvauksen digitalisoitumisen mukanaan tuomat muutokset sekä tekniikan että käytäntöjen tasolla olivat alkaneet näkyä myös valokuvausta koskevissa teoreettisissa keskusteluissa perinteisten asetelmien liikahduksina. Suomen valokuvataiteen museollakin 1990-luvun puolivälissä esillä ollut "Photography after Photography" -näyttely ja sitä saatellut katalogi ovat ehkä leimallisin esimerkki tästä murroksesta. Analogiseen ja digitaaliseen jakautuneella valokuvauksella ei tuntunut olevan mitään selkeästi tunnistettavaa olemuksellista ydintä. Valokuvauksen digitalisoituminen rinnastettiin mittavuudeltaan jopa foneettisen kirjoituksen, kirjapainotaidon ja keskeisperspektiivimenetelmien keksimisen mukanaan tuomiin kulttuurisiin murroksiin. Seppänen päätyi kannattamaan anti-essentialistista näkemystä, jonka mukaan valokuvaus hahmottui vain ja ainoastaan kulttuurisen kontekstinsa välityksellä. Anti-essentialistin näkökulmasta valokuvan olemuspohdinta on turhaa puuhaa, sillä valokuvaa sinänsä ei ole. 
Levoton valokuva on toista maata; se rakentuu valokuvan materiaalisen ytimen ajatuksen varaan. Näkökulman muutos on huomattava. Valokuvalla on siis sittenkin konteksteihin palautumaton ydin. Keskeinen kysymys ei koske enää valokuvan identiteettiä vaan sitä "miten valokuva on olemassa?". Tähän kysymykseen kirjassa haetaan vastauksia valon jättämän jäljen ajatuksen avulla. Levoton valokuva on lähtökohdiltaan eräänlainen paluu valokuvan olemuspohdinnan ydinkysymyksiin.

Ydinfysiikan teorioiden pohjalta tiedämme, ettei atomi nimestään huolimatta ole jakamaton. Ydintä voidaan purkaa, jopa niin pitkälle, että materian ja energian ero alkaa hämärtyä. Samalla itse purkuoperaatiota määrittää epätarkkuusperiaate: kohde ja metodi kietoutuvat toisiinsa. Vastaava asetelma määrittää valokuvan materiaalisen ytimen jäljitystä. Seppänen tunnistaa tämän asetelman, vaikkei lähdekään erittelemään sen teoreettisia seuraamuksia:

Myös käsillä oleva kirja on eräänlainen jälki kohtaamisesta materiaalisen ytimen kanssa. Riveille on jäänyt se, mitä olen kohtaamisesta tekstiksi osannut kirjoittaa. Rivien väleihin, aukkoihin ja ristiriitoihin kirjan toinen tekijä on jättänyt omat merkintänsä. Joskus hieman vinosti hymyillen, luulisin.

Kvanttitason tapahtumat vaativat toisenlaista selitysperustaa kuin silminnähtävät kohteet ja käsin kosketeltava aines. Suuri materiaalisuuden yhtenäisteoria alkeishiukkasista hippuihin ja kappaleisiin, maan kamaraan ja taivaan tähtiin on vähintäänkin haasteellinen. Levottoman valokuvan hahmottelema valokuvan materiaalisen ytimen ajatuksen jänneväli on samaa luokkaa, vaikka tavoitteena ei olekaan yhtenäisteoria.

Jonkinlaista siltaa Levoton valokuva kuitenkin rakentaa yhteiskuntatieteellisen valokuvatutkimuksen ja fysiikan välille. Seppänen asettaa tavoitteekseen hahmottaa valokuvan materiaalista ydintä "sekä fysikaalisena että sosiaalisena ilmiönä”. Kirjan sivuilla jäl- jestä puhutaan valokennojen sähkövarauksiin, filmiemulsion kemiallisiin reaktioihin, havaintomaailman reunaehtoihin ja diskursseihin vedoten. Maasto on heterogeeninen, ja materiaalisen ytimen ja jäljen käsitteille asettuvat haasteet sitä myöten melkoiset.

Kun "mikä" väistyy teoretisoinnin johtokysymyksen asemasta ja tilalle astuu "miten", niin tapahtuu myös siirtymä merkityksistä merkityksellisyyteen. Diskurssien ja representaatioiden ohella huomio alkaa kiinnittyä affektiivisuuteen, inhimillisen toiminnan materiaalisiin olosuhteisiin ja ei-inhimillisten toimijoiden vaikutuksiin ihmisten maailmassa. Näihin teemoihin kytkeytymällä Levoton valokuva etääntyy representaatioihin keskittyvästä visuaalisen kulttuurin tutkimuksesta ja asemoi itsensä osaksi ajankohtaisia kulttuuriteoreettisia keskusteluja.

Suomalaisen valokuvatutkimuksen kontekstissa tämä painopisteen muutos on varsin tervetullut. Viestinnällisiin, taiteellisiin ja mediateoreettisiin teemoihin keskittyvää suomenkielistä valokuvatutkimusta on julkaistu viimeisten parinkymmenen vuoden aikana kiitettävästi, kun taas materiaalisen kulttuurin ja läpikameraistuneen yhteiskunnan kysymyksiin nivoutuva valokuvateoreettinen keskustelu on meillä vasta viriämässä. Kansainvälisesti tilanne on jo toinen.

Aivan uusi avaus Levoton valokuva ei meilläkään ole. Useat kirjassa käsitellyistä teemoista ovat olleet esillä suomenkielisissäkin valokuvausta sivuavissa keskusteluissa, tosin lähinnä konteksteissa, joita ei usein mielletä valokuvatutkimuksen piiriin kuuluviksi, kuten näyttelykatalogit ja taiteellisen tutkimuksen julkaisut. Välinekeskeisten lähtökohtien kyseenalaistuminen mediakäytännöissä, taiteessa ja tutkimuksessa on johtanut myös valokuvatutkimuksen keskustelukontekstin hajaantumiseen.

Levoton valokuva jakautuu kahteen osaan, joista ensimmäinen erittelee valon kuvautumista ja toinen valokuvan materiaalisen ytimen ja inhimillisten toimijoiden kohtaamisia. Kirjan yksittäiset osiot, joissa käsitellään muun 
muassa erilaisia kameroita camera obscurasta digikameraan, merkin ja representaation käsitteitä, brittiläisen kulttuurintutkimuksen piirissä virinnyttä ideologiakriittistä valokuvakeskustelua, Roland Barthesin Valoisaa buonetta ja John Szarkowskin modernistisia näkemyksiä, ovat informatiivisia mutta hieman oppikirjamaisia.

Ainesten yhdistelmä puolestaan on omaperäinen. Seppäsen johtoajatuksena on lukea diskursseja, teknisiä apparaatteja ja valokuvauskäytäntöjä materiaalisen jäljen näkökulmasta. Kyseessä on eräänlainen ajatuskoe, jonka tavoitteena on koetella materiaalisen jäljen tarjoaman lähtökohdan kantavuutta. Seppänen perustelee lähestymistapaansa vetoamalla James Gibsonin tarjouman (affordance) käsitteeseen. Kyse on valokuvan materiaalisen ytimen toimijuuden hahmottelemisesta diskurssien, teknologioiden ja käytäntöjen tasolla.

Seppänen rajaa tutkimuksensa kameran avulla muodostettuihin liikkumattomiin kuviin. Pois rajautuvat monenlaiset valon jättämät jäljet, kuten rusketusrajat ja fotogrammit, mutta myös kuvatiedostot, joiden avulla valotusajan puitteissa tapahtuneita muutoksia voidaan esittää jatkumona. Rajaus on toisaalta perusteltu ja tarpeen, jotta monitahoisiin asiayhteyksiin saadaan jonkinlaista tolkkua. Toisaalta rajaus on ongelmallinen ja heikentää Seppäsen käsitteellisten erottelujen voimaa. Tässä mielessä kuvaava on se tapa, jolla Seppänen kehittelee materiaalisen jäljen ajatuksen tarjoumaa valokuvateoreettisen indeksisyyskeskustelun suhteen.

Charles Sanders Peircen merkkiteoriasta juontuva indeksisyyden käsite on muodostunut yhdeksi valokuvateorian avainkäsitteeksi. Peircen keskeisimmät esimerkit indeksisestä merkkifunktiosta ovat tunnetusti sormenjälki ja tuuliviiri. Valokuvateoreettisissa keskusteluissa valon piirtämää jälkeä on tältä pohjalta pohdittu lähinnä kausaalisuhteen ja jatkumon näkökulmasta. Monimuotoinen autenttisuuden retoriikan valtavirta on suosinut ajatusta siitä, että näkyvän jäljen totuudellisuuden tae on sen indeksinen perusta. Tällainen realismikäsitys, jota voisi kutsua "haptiseksi realismiksi", on linjassa länsimaista ajattelua laajalti kannattelevan haptosentrismin kanssa. Sen näkökulmasta kosketus näyttäytyy paitsi välittömänä kontaktina ja sitä myöten aistivarmuuden takeena myös optisen intuitionismin ja sen varaan rakentuvien teoreettisten jäsennysten perustana. Tässä ajattelukehikossa valon jättämä jälki rinnastuu poissaolon näkyvään läsnäoloon.

Levoton valokuva onnistuu horjuttamaan tätä asetelmaa, sillä Seppäsen jäljittämä jälki ei ole ytimeltään mitään näkyvää. Siinä on kyse elektronien liikkeen aiheuttamista muutoksista atomitasolla. Seppäsen hahmottelemasta näkökulmasta valokuvan materiaalinen ydin on latentti jälki. Ajatus ei sinällään ole uusi. Suomalaisessakin valokuvatutkimuksessa on lyöty kiilaa ikonisen ja indeksisen merkkiaspektin väliin monin tavoin. Valojälkeä on tarkasteltu suhteessa kaltaisuuteen, sokeuteen, pyhään, "negatiivin hetkeen" ja différanceen. Uusi ja rohkea sen sijaan on Seppäsen yritys silloittaa atomitason ja havaintomaailman välistä kuilua. Tähän paikantuvat myös Levottoman valokuvan käsitteellisesti haasteellisimmat askeleet.

Seppänen ottaa vauhtia Göran Sonessonin esittämästä argumenttista, jonka mukaan valokuvassa ei itse asiassa ole nähtävissä suoria jälkiä objekteista vaan niiden pinnasta sekä valokuvausapparaatin eri osista heijastuneista fotoneista. Seppänen ehdottaa, että erittelyä pitäisi tarkentaa pohtimalla lisäksi emittoituneen ja heijastuneen valon eroa. Emission tapauksessa nimittäin myös kohde itse voi jättää jälkensä valoherkkään alustaan. Atomistasolla tehty erottelu reflektion ja emission välillä ei kuitenkaan voi olla pitävä havaintomaailman kohteiden suhteen, sillä kyse on taajuuseroista aina absoluuttiseen nollapisteeseen saakka,jossa on oletettavasti myös absoluuttisen pimeää. Sähkömagneettisia ilmiöitä koskevien teorioiden pohjalta voisi yhtä hyvin päätyä väittämään, että kaikki valokuvat ovat lämpökuvia. 
Seppänen paikantaa valokuvan levottoman liikkeen lähinnä inhimillisten toimijoiden ja materiaalisen ytimen välisiin kohtaamisiin. Levoton valokuva antaa kuitenkin aineksia ajatella liikettä vielä paljon laajemmin. Vastaavalla tavalla kuin havaittavien kohteiden tasolla silmän liike on paitsi näköhavainnon myös valokuvan ehto, atomitasolla elektronien liike on valon kuvautumisen ehto. Valokuvan ytimessä onkin liikettä.

Vastaavanlaisen spagaatin atomitason ja inhimillisen todellisuuden välillä voisi tehdä myös kosketuksen termein, sillä se mikä koskettaa myös liikuttaa sanan kaikissa merkityksissä.

- MIKA ELO 